\title{
Yellow lupin (Lupinus luteus L.) transcriptome sequencing: molecular marker development and comparative studies
}

Lorena B Parra-González ', Gabriela A Aravena-Abarzúa', Cristell S Navarro-Navarro', Joshua Udall², Jeff Maughan², Louis M Peterson ${ }^{2}$, Haroldo E Salvo-Garrido ${ }^{1,3}$ and Iván J Maureira-Butler ${ }^{1 *}$

\begin{abstract}
Background: Yellow lupin (Lupinus luteus L.) is a minor legume crop characterized by its high seed protein content. Although grown in several temperate countries, its orphan condition has limited the generation of genomic tools to aid breeding efforts to improve yield and nutritional quality. In this study, we report the construction of 454-expresed sequence tag (EST) libraries, carried out comparative studies between L. luteus and model legume species, developed a comprehensive set of EST-simple sequence repeat (SSR) markers, and validated their utility on diversity studies and transferability to related species.

Results: Two runs of 454 pyrosequencing yielded $205 \mathrm{Mb}$ and $530 \mathrm{Mb}$ of sequence data for L1 (young leaves, buds and flowers) and L2 (immature seeds) EST- libraries. A combined assembly (L1L2) yielded 71,655 contigs with an average contig length of 632 nucleotides. L1L2 contigs were clustered into 55,309 isotigs. 38,200 isotigs translated into proteins and 8,741 of them were full length. Around $57 \%$ of L. luteus sequences had significant similarity with at least one sequence of Medicago, Lotus, Arabidopsis, or Glycine, and $40.17 \%$ showed positive matches with all of these species. L. luteus isotigs were also screened for the presence of SSR sequences. A total of 2,572 isotigs contained at least one EST-SSR, with a frequency of one SSR per $17.75 \mathrm{kbp}$. Empirical evaluation of the EST-SSR candidate markers resulted in 222 polymorphic EST-SSRs. Two hundred and fifty four (65.7\%) and 113 (30\%) SSR primer pairs were able to amplify fragments from L. hispanicus and L. mutabilis DNA, respectively. Fifty polymorphic EST-SSRs were used to genotype a sample of 64 L. luteus accessions. Neighbor-joining distance analysis detected the existence of several clusters among L. luteus accessions, strongly suggesting the existence of population subdivisions. However, no clear clustering patterns followed the accession's origin.
\end{abstract}

Conclusion: L. luteus deep transcriptome sequencing will facilitate the further development of genomic tools and lupin germplasm. Massive sequencing of cDNA libraries will continue to produce raw materials for gene discovery, identification of polymorphisms (SNPs, EST-SSRs, INDELs, etc.) for marker development, anchoring sequences for genome comparisons and putative gene candidates for QTL detection.

Keywords: Lupinus luteus, EST-SSR, Orphan crop, Microsynteny

\footnotetext{
* Correspondence: ivan.maureira@cgna.cl

${ }^{1}$ Agriaquaculture Nutritional Genomic Center, CGNA, Genomics and Bioinformatics Unit, Km 10 Camino Cajón-Vilcún, INIA, Temuco, Chile Full list of author information is available at the end of the article
} 


\section{Background}

L. luteus is a member of the genistoid clade of the Fabaceae family $(2 \mathrm{n}=52)$, which is the third largest flowering plant family with over 700 genera and 20,000 species [1]. The genus Lupinus comprises more than 200 annual and perennial herbaceous species of which several are cultivated and used as human food or animal feed [2]. Some of them show high levels of tolerance to biotic and abiotic stresses. For instance, L. hispanicus, a wild relative of L. luteus, has high tolerance to diseases and good adaptation to poor soils, but high levels of bitter alkaloids and low agronomic yields [3]. Lupins are considered to be of polyploid origin which probably played a crucial role in the evolution of their ancestral genomes $[4,5]$. The major cultivated species are the old world lupin L. albus (white lupin), L. angustifolius (narrowleafed lupin), L. luteus (yellow lupin), and the new world species L. mutabilis (pearl lupin or tarwii) [6].

L. luteus is widely distributed across the Mediterranean region, has shallow soil requirements, and cultivated accessions have variable seed yields in Mediterranean environments [7]. In addition, yellow lupin seeds have the highest protein content and twice the cysteine and methionine content of most lupins $[8,9]$. However, despite its highly nutritional qualities, there is a lack of genetic and molecular tools to aid the genetic breeding of this species.

EST sequencing has accelerated gene discovery when genome sequences are not available, facilitating gene family identification and development of molecular markers. Next-generation sequencing has generated enormous amount of expressed sequence data for a wide number of plant species, specially minor or orphan crops [10]. For example, EST and genome sequencing of lentil and chickpea would not have been feasible without next-generation sequencing $[11,12]$. The lower cost and greater sequence yield has allowed the identification of candidate genes, even when they are expressed at low levels $[13,14]$.

Research on plants, animals and fungi has shown that sequences of expressed genes are often widely transferable among species, and even genera, allowing wide genome comparative mapping studies $[15,16]$. For instance, the combination of orphan crop EST sequences with model plant genetic and genomic resources, such as Lotus japonicus (Japanese trefoil) and Medicago truncatula (barrel medic), has identified macro- and micro-scale synteny, discovered new genes and alleles, and provided insights into genome evolution and duplication [17,18]. Comparisons between ESTs and gene sequences among several legume species have allowed comparative genome studies between L. albus and M. truncatula [19], and L. angustifolius and Lotus japonicus [20].
Several molecular markers have been developed for Lupinus species, including RFLPs, ITAPs (Intron targeted amplified polymorphic sequences), and AFLPs, which have been used to build genetic linkage maps in L. albus [19] and L. angustifolius [20,21]. So far, a limited number of SSRs have been developed for Lupinus species, and very few of these are EST-SSRs i.e. SSRs that are found in expressed sequences [21-23]. Genomic and EST-SSRs have been widely used for the improvement of major crop plants, but their initial development with traditional methods requires significant research investment. Now, an almost unlimited number of genomic and EST-SSRs can be readily developed from nextgeneration sequencing approaches within most crop species, including orphan crops such as lupin [24-28]. The expressed nature of EST-SSRs allows the annotation of these markers with putative functions by sequence homology and potentially reduces the genetic distance between marker and causal gene to $0 \mathrm{cM}$. [29,30]. For instance, the length of a dinucleotide SSR at the 5' UTR of a waxy gene has been associated with amylase content in rice [31,32]. EST-SSRs have also been associated with several disease resistant genes in wheat and rice $[33,34]$ and a number of agronomically important traits in cotton, maize and narrow-leafed lupin [35-37].

In this study, we constructed 454-EST libraries, carried out comparative studies between L. luteus and model legume species, and mapped L. luteus expressed sequences on the $M$. truncatula chromosomes. Alignments between our putative L. luteus genes and their homologs in $M$. truncatula, coupled with amplifications of intergenic regions provided evidence of microscale synteny between both species. In addition, we developed EST-SSR markers and illustrated their utility within diverse accessions of yellow lupin. Finally, because these EST-SSR markers are gene-based, they are also likely conserved among different species of lupin. We evaluated EST-SSR utility in the other Lupinus species, L. mutabilis and L. hispanicus.

\section{Methods}

\section{Library construction and 454 sequencing}

cDNA libraries were constructed from mRNA isolated from two tissue pools. Pool 1 (L1) included young leaves, buds and flowers, and pool 2 (L2), seeds in different developmental stages. RNA from pool 1 and 2 was isolated separately according to the guanidine hydrochloride method [38]. Both RNAs were assessed for quality by inspecting rRNA bands on an Agilent Bioanalyzer (Agilent Technologies, CA, USA).

cDNAs libraries were normalized and prepared using procedures for Roche 454 Titanium sequencing (Roche, Branford, CT, USA). cDNAs from L1 and L2 were 
synthesized using the stratagene AccuScript High Fidelity RT-PCR System (Agilent Technologies, CA, USA) and 5' specific adaptors from Clontech. A cDNA normalization was used to improve coding sequence coverage, avoid AT homopolymer artifacts, and reduce excessive 3' end transcript sequence [39]. cDNAs from both libraries were amplified using the Clontech Advantage HF system (Clontech Laboratories, Inc) and normalized utilizing the Evrogen Trimmer cDNA Normalization kit (Axxora, LLC). These un-cloned, normalized cDNA libraries were prepared for pyrosequencing according to the manufacturers specifications. One 454 run of sequencing was performed for each EST library (454 Life Sciences, Roche).

Separate transcriptome assemblies of L1 and L2 libraries were created using Newbler (de novo sequence assembly software of Roche 454 Life Sciences) and the cDNA option. A third assembly (L1L2) was completed using the reads from both libraries to avoid sequence redundancy when developing SSR markers. Reads were initially assembled into contigs and contigs into isotigs, which are equivalent to splice transcriptional variants. Sequence read EST data for L1 and L2 are available through the Sequence Read Archive (SRA055806).

\section{EST annotation, function and comparative genomics to other species}

Comparing isotigs from the combined assembly (L1L2) to the curated non-redundant protein database (nr, www.ncbi.nlm.nih.gov; blastx, e value $\leq 1 \mathrm{e}^{-10}$ ) provided a functional annotation for each isotig. Alignments of translated-isotigs and proteins with an e-value $\leq 1 \mathrm{e}^{-40}$ were considered to have significant homology. Annotations of the aligned proteins were extrapolated to annotate our putative isotig sequence using Blast2GO (www. blast2go.org). To directly compare the lupin isotigs to the genes of other crops, blast searches were also used to compare isotig translations to Arabidopsis thaliana, Glycine max, Medicago truncatula and Lotus japonicus Gene Indices (tblastx, e-value $\leq 1 \mathrm{e}^{-10}$ ). Isotigs were also annotated using Gene Ontology (GO) annotations from InterProScan (www.ebi.ac.uk).

\section{In silico lupin EST mapping and microsynteny}

Blast was used to compare lupin EST isotigs to the Medicago genome 3.0 release $\left(\leq 1 \mathrm{e}^{-20}\right.$, HSP identity $60 \%$ and HSP length $>50$ bp.) The Blast results were visualized using GBrowse where positive matches were displayed as featured tracks on GBrowse 2.13 [40]. The presence of microsynteny was evaluated by PCR amplification of putatively conserved chromosome blocks between $L$. luteus and $M$. truncatula. Where alignments between yellow lupin and $M$. truncatula were identified, specific primer pairs were designed to amplify intergenic regions (Additional file 1). These targeted, intergenic regions were PCR amplified from two L. luteus and one L. hispanicus accessions using $100 \mathrm{ng}$ of genomic DNA in $20 \mathrm{ul}$ reactions containing $100 \mathrm{ng}$ of genomic DNA, $0.2 \mathrm{mM}$ dNTPs, $2 \mathrm{mM} \mathrm{MgCl2,} \mathrm{1X} \mathrm{PCR} \mathrm{buffer,} \mathrm{2.5 \%} \mathrm{DMSO,} 1 \mathrm{U}$ taq polymerase (Agilent Technologies, Santa Clara, CA) and 5 pmoles of each forward-reverse primer pair. PCR reactions were carried out following a touchdown proto$\mathrm{col}$ on a peltier thermalcycler (MJ Research, Inc.) $94^{\circ} \mathrm{C}$ for $5 \mathrm{~min} ; 5$ cycles of $1 \mathrm{~min}$ at $94^{\circ} \mathrm{C}, 1 \mathrm{~min}$ at $55-65^{\circ} \mathrm{C}$ decreasing $1^{\circ} \mathrm{C}$ per cycle, $2 \mathrm{~min}$ at $72^{\circ} \mathrm{C}$ followed by 35 cycles of $1 \mathrm{~min}$ at $94^{\circ} \mathrm{C}, 1 \mathrm{~min}$ at $50-60^{\circ} \mathrm{C}$ and $2 \mathrm{~min}$ at $72^{\circ} \mathrm{C}$. Amplicons were purified from agarose gels and sequenced. These amplified, intergenic sequences were mapped onto the $M$. truncatula genome and visualized within a local implementation of GBrowse (Additional file 1). Positive PCR microsynteny set of primers were additionally tested against a screening panel consisting of six diverse accessions of L. luteus to search for polymorphisms among yellow lupin genotypes (Additional file 2).

\section{Identification of EST-SSRs}

SSR containing lupin isotigs were identified using the software MISA (MIcroSAtellite, http://www.pgrc.ipkgatersleben.de/misa). SSR search criteria changed according to repeat types. $\mathrm{Di}-$, and tri-repeats were selected with a minimum length of 12 and 15 nucleotides, respectively. For tetra-, penta- and hexa-repeats, the minimum length was 20 nucleotides. Mononucleotide repeats were not considered due to the possibility of 454 homopolymer sequencing errors associated with this technology. To estimate the amount of SSRs included in coding regions, L1L2 sequences were analyzed using ESTScan (http:// www.ch.embnet.org/software/ESTScan.html). ORFs discovery was carried out using default parameters and putative cd sequences scanned for SSR motifs using MISA.

From all selected-SSR containing isotigs, only sequences with a motif of at least 7 repeat units were considered for primer design. Flanking primer pairs were designed using the Primer3 software available at NCBI v.3.12 with expected amplicon lengths between 150 $500 \mathrm{bp}$. Oligonucleotides were synthesized by IDT (Integrated DNA Technologies, Inc.).

\section{Evaluation and utility of EST-SSRs}

EST-SSR polymorphisms and transferability were evaluated on the germplasm screening panel previously mentioned, and one accession each of L. hispanicus and L. mutabilis.

DNAs were extracted following standard procedures [41], quantified using a synergy HT Multimode Microplate Reader (Biotek Instruments, Winooski, VT), and diluted to $50 \mathrm{ng} / \mathrm{ul}$ in TE buffer (10 Mm TRIS, $1 \mathrm{mM}$ 
EDTA pH 7.5). DNA amplification was carried out in 20ul PCR reactions as described above.

PCR products were separated on $6 \%$ denaturing polyacrylamide gels, run in TBE buffer at 60 watts for 34 hours and visualized using silver stain procedures. DNA amplicons of six EST-SSR primer-pairs used in the polymorphism screening were purified from agarose gels and sequenced in an Applied Biosystems 3730xl DNA Analyzer sequencer (Applied Biosystems, Carlsbad, CA). Amplicon sequences from each EST-SSR primer-pairs were aligned using Geneious version 5.5.3.0 (Biomatters Ltd., using default parameters).

\section{Genetic diversity}

The polymorphic EST-SSRs were evaluated in sixty-four L. luteus accessions from several origins (Poland, Ukraine, the former Soviet Union, Spain, Germany, Morocco, Belarus, Portugal, Netherlands, Israel, Hungary, and Chile; Additional file 2). Polish accessions were kindly provided by W.K. Swiecicki, Institute of Plant Genetics, Polish Academy of Sciences, Poznan. Our collection of Chilean accessions is composed of improved breeding lines that are adapted to the Chilean environment. This Chilean germplasm originated from breeding and selection of old European varieties for Southern Chilean environmental conditions. The rest were obtained from the western Regional PI Station, USDA, ARS, WRPIS, Washington State University, Regional Plant Introduction Station, Pullman, Washington, USA. A sample of 50 polymorphic EST-SSRs was used to genotype the sixty-four L. luteus accessions (Table 1). Eighteen EST-SSRs were identified from isotigs specific to L2, 25 isotigs specific to L1, and seven were common to both L1 and L2 libraries. EST-SSR fragments with different sizes were scored as different alleles and coded with alphabetical letters for each primer set. Genetic relationships among L. luteus accessions were evaluated using the neighbor-joining algorithm implemented in PAUP* (v4.01b10). A distance tree was built and branch support estimated by 10,000 bootstraps.

\section{Results}

\section{Seed and leaf-flower EST libraries}

Two runs of 454 pyrosequencing yielded $205 \mathrm{Mb}$ and $530 \mathrm{Mb}$ of sequence data for L1 and L2 EST libraries, respectively (Table 2). L1 produced 604,869 usable reads that assembled into 26,975 contigs with an average length of 468 nucleotides. L2 generated 1,345,892 usable reads that assembled into 43,674 contigs with an average length of 800 nucleotides. Careful inspection of the L1 contigs found lower percentages of coding regions, higher $\mathrm{A} / \mathrm{T}$ content, and $2 \mathrm{x}$ more $\mathrm{A} / \mathrm{T}$ homopolymers than L2 contigs. A combined assembly (L1L2) was created to identify the genes that were common in both tissues. $1,964,517$ reads were used in the L1L2 assembly and they formed 71,655 contigs with an average contig length of 632 nucleotides. To reduce sequence redundancy due to transcript and alternative splice variants, L1L2 contigs were clustered into 55,309 isotigs, of which 38,200 isotigs translated into proteins and 8,741 of them were full length.

\section{Functional classification and in silico comparative genomics}

The assembled 454 isotigs represented putative transcriptional products i.e. functional genes. Blastx was used to annotate the L1L2 putative genes (i.e. isotigs). A total of $32,862(59.5 \%)$ putative genes showed matches with other species $\left(\leq 1 \mathrm{e}^{-10}\right)$. Of these sequences, 20,169 (36.5\%) showed high similarity to other plant species genes $\left(\leq 1 \mathrm{e}^{-40}\right)$. GO annotations were grouped under three categories: molecular function, biological processes, and cellular components (Figure 1). At least 31,142 isotigs were annotated with one molecular function, 11,894 with a cellular component and 22,842 with biological process.

Blast was used to compare L1L2 to several model species (tblastx; $\leq 1 \mathrm{e}^{-10}$; Figure 2). Around $57 \%(31,520)$ of L. luteus sequences had significant similarity with at least one sequence of Medicago, Lotus, Arabidopsis, or Glycine, and $40.17 \%$ showed positive matches with all of these species.

\section{In silico mapping of lupin ESTs on M. Truncatula chromosomes}

Alignment of $L$. luteus isotig sequences to the M. truncatula genome (Blastn; $\leq 1 \mathrm{e}^{-20}$; MT3) was used to identify local genomic variability between our ESTs and a related, well-annotated reference genome sequence. The alignments were visualized using GBrowse (v. 2.13) with the Blast matches displayed as feature tracks. A total of 25,400 sequences (46\%) from L1L2 had a positive match with MT3 and were distributed heterogeneously on the M. truncatula chromosomes. Chromosomes 3 and 1 had the highest $(34,636)$ and lowest $(16,055)$ number of matches, respectively. Each $L$. luteus sequence was mapped to an average of 3.7 positions on the Medicago genome.

Occasionally, independent alignments of lupin genes with the $M$. truncatula genome were found relatively close to each other that primers could be designed to hybridize conserved exons, allowing the amplification of intergenic sequences in between lupin and $M$. truncatula coding sequences (Figure 3). Positive PCR amplification of intergenic regions using L. luteus genomic DNA and primers anchored on conserved exonic regions of adjacent $M$. truncatula genes suggested the occurrence of microsynteny (i.e. conserved gene order) 
Table 1 Characteristics of 50 EST-SSR primers developed in L. luteus. Shown for each primer pair are the library specificity, repeat motif, forward and reverse sequence, allele range size (bp), number of alleles, amplification in other Lupin species, and annotation

\begin{tabular}{|c|c|c|c|c|c|c|c|c|}
\hline Marker name & Library & Repeat motif & Forward primer $\left(5^{\prime}-3^{\prime}\right)$ & Reverse primer $\left(5^{\prime}-3^{\prime}\right)$ & Size (bp) & No of alleles & Amplification & Annotation \\
\hline I112itg33000 & L1 & $(A C A) 7$ & CACGTCAGTCCTTGCACCTA & GCACAGCAACAACAACACAA & $129-132$ & 2 & L.hispanicus & \\
\hline |112itg51784 & L1 & $(\mathrm{TA}) 8$ & СATCСTTCAAAAACCATTTCAA & AATGTTGATGAACGCGTGTG & $274-280$ & 3 & & \\
\hline |112itg52347 & L1 & (AT)8 & CTCATGTTTCTTGGGTGGAAA & CAATCATGTCTAAACCGGGAA & $209-215$ & 4 & & \\
\hline |112itg50343 & L1 & (AT) 10 & ATATTAGCGGCCATGCTGTT & TGTTCATGTTGGTTGCAAGA & $235-239$ & 3 & & \\
\hline |112itg20858 & L1 & $(\mathrm{AAC}) 12$ & АССССАСТTСТСССААСТСТ & TCCATGAATGAAATGGGGTT & $229-238$ & 3 & L.hispanicus & $\begin{array}{c}\text { Pollen-specific } \\
\text { protein SF3 }\end{array}$ \\
\hline |1|2itg20038 & L1 & $(\mathrm{TA}) 9$ & TTCAGAAACAAAGGGGTTGC & TCCAGAAATTCTTCTACATCCCA & $179-183$ & 3 & & \\
\hline |112itg52625 & L1 & (TCA) 12 & CTGGTCTTCTGTCGACTCCA & GACCAAGAAGTCAAGCTCGG & $109-124$ & 4 & & \\
\hline |112itg37631 & L1 & $(\mathrm{CT}) 12$ & TAAAGTGCCACCAACAAGCA & TTGTGTTGGTTGTGTGTAGAGAGA & 133-155 & 6 & & \\
\hline |112itg27097 & L1 & $(\mathrm{AAT}) 7$ & TTCAACTACCGGTTGAACCAC & GCCCAGAATTAGGGTGCTTT & $206-209$ & 2 & & \\
\hline |112itg22424 & L1 & $(\mathrm{GAA}) 7$ & AAACGACCAACCGCATAAAG & GATGCGTGAAACTGCAAAGA & $240-249$ & 3 & L.hispanicus & $\begin{array}{l}\mathrm{N} \text {-acetylglutamate } \\
\text { synthase }\end{array}$ \\
\hline |1|2itg29703 & L1 & $(G A) 8$ & ACCTTTGCGCCAAGATACAC & ATTGTGACGGTTTCACTCCC & 213-219 & 4 & & \\
\hline |112itg28437 & L1 & $(\mathrm{TA}) 9$ & GGGCACATTTGACTCTTTCG & TCCGTGCAATGTCAATATCAA & $260-268$ & 4 & L.hispanicus & \\
\hline |1|2itg36804 & L1 & (ATA) 12 & CACATGAGAAGCAGCAATGAA & ATGCGGTGGAGTGGAAGTAA & $254-260$ & 2 & L.hispanicus & \\
\hline |1|2itg21177 & $L 1, L 2$ & (CAT) 8 & CCTTGAGGCCAATAAATGGA & TTAAGGAAGCTAGGGCCACA & $217-226$ & 3 & L.hispanicus & Delta-8 sphingolipid desaturase \\
\hline |112itg39645 & L1 & (ATT)10 & AATCATGGCCTITITGCTTG & CGTCTTGCTCTGGTTCTTCC & $148-169$ & 5 & & \\
\hline |112itg35309 & L1 & $(\mathrm{TA}) 8$ & TTCATGGCAAGAAAAACATCT & AATCATCCATGCCATTTAACA & $271-281$ & 4 & & \\
\hline |112itg56943 & L1 & $(G A) 8$ & GAGGCCCAAAAACAGAAACA & CCATTTGCGTTCGGTTCTAT & $270-272$ & 2 & L.hispanicus, L.mutabilis & \\
\hline |112itg31693 & L1 & $($ TAT) 8 & AGGGGCAAAGCTCAAAGACT & CATTCACATTTATCCTCATTGACTC & $196-217$ & 4 & L.hispanicus & \\
\hline |1|2itg10347 & L1 & (AT)8 & TGTGGTAAATGCAGGCTCAG & ATGCAACGGGAACCATAGTC & 184-186 & 2 & L.hispanicus & \\
\hline |112itg14618 & L1 & $(\mathrm{CAT}) 7$ & ТТССТСАТСТСССАСАССТС & AGCTTCTGCTTGTAATCGGC & $237-252$ & 4 & & \\
\hline |112itg20466 & $\mathrm{L} 1, \mathrm{~L} 2$ & $(\mathrm{TA}) 9$ & GTAATCATTCATGTATAATTGTAACACTC & CAATTCATTATCTGTATTATTACCCC & $180-186$ & 3 & & Cytochrome B561 \\
\hline |112itg53474 & $\mathrm{L} 1, \mathrm{~L} 2$ & $(G A) 10$ & CTGAAGTGAGGTTCGGGAAG & TCAATCACACATGCTTGTTCC & $230-234$ & 3 & & Cullin-1 \\
\hline |112itg51894 & L1 & (AT) 10 & TGACTTGATTGTTAAGCTTACAGG & TGAATGTCAAATGCAATATTAAGGA & $247-263$ & 3 & L.hispanicus & \\
\hline |112itg24819 & L1 & (AT)8 & САTTCATTCTCTAATCTTTTGTGTCA & TAAAGCTTGTCTCTTGCCCG & $219-244$ & 5 & L.hispanicus & \\
\hline |112itg55310 & L1 & (TA)9 & ACCAAAAGGGTGGGTGAAAT & CCTAACATTTGAACATATTTAAAACAA & $277-283$ & 4 & & \\
\hline |1|2itg14694 & $\mathrm{L} 1, \mathrm{~L} 2$ & $(\mathrm{TA}) 8$ & AAGTAGGAAGATCGAATATGAACG & GGGAAAATATCGAGGTTTTCATC & $268-278$ & 3 & L.hispanicus, L.mutabilis & RNA-binding protein \\
\hline |112itg35641 & L1 & (AT)8 & AGTTGCAATTCAACAACGCA & CATGCTCTATGGCAAGTGCT & $247-251$ & 3 & & \\
\hline |112itg38340 & L1 & (TAT)7 & AGCTCCACTITTAGAATTGCG & TCTATTGTTACATGCACATTATCCC & $164-173$ & 4 & L.hispanicus & \\
\hline |112itg26293 & L2 & (TCCGAA)15 & CCTGCAGTGGTAGAACCTGG & GAAGCAAGGTCCACAGAAGG & $123-183$ & 6 & & $18 \mathrm{~S}$ ribosomal RNA gene \\
\hline
\end{tabular}


Table 1 Characteristics of 50 EST-SSR primers developed in L. luteus. Shown for each primer pair are the library specificity, repeat motif, forward and reverse sequence, allele range size (bp), number of alleles, amplification in other Lupin species, and annotation (Continued)

\begin{tabular}{|c|c|c|c|c|c|c|c|c|}
\hline |112itg42878 & L2 & (САТТCC) 11 & CAACTCTTGTTTGCAGACCG & GCTACCCTTTCGGGACTAGC & 217-235 & 4 & L.hispanicus, L.mutabilis & \\
\hline |112itg13749 & L2 & (TTCCGC)8 & TIITACTCGACTCGCTCCC & CCAGTCGATTTAGCAGTCGC & $207-261$ & 7 & L.hispanicus, L.mutabilis & \\
\hline |112itg32760 & $L 1, L 2$ & (CGGAAT)14 & TCATAATGAATTAAATTAACCCCC & TCCCTGACTCTGTCTTTGGG & $146-284$ & 14 & L.hispanicus & \\
\hline |112itg00675 & L2 & (TCT)8(TCG)5 & AGAGAGATCCTCTTTGACGCC & GTGGTTAGCGAGAACCATCG & 187-199 & 4 & & BSD domain-containing protein \\
\hline |112itg45631 & L2 & (ATC) 10 & AAACCGAATTGTGGATCAGC & GGGGACTCTGGAAAATCAGG & $146-155$ & 3 & L.hispanicus, L.mutabilis & Alphavirus core protein family \\
\hline |112itg20349 & L2 & $(\mathrm{AAC}) 7$ & ACTAAGGGAAAGGGATTCGG & CCAGGCAAGAACAAAAGAGG & 186-189 & 2 & L.hispanicus, L.mutabilis & LPA2 (low psii accumulation2) \\
\hline |112itg41827 & L2 & (TTG)7 & TTGAGTCATATCACCATAGCGG & CAACCACAAATGGAAAACCC & $242-245$ & 2 & L.hispanicus, L.mutabilis & Lipase class 3 family protein \\
\hline |112itg47916 & L2 & $(\mathrm{TCT}) 9$ & GGTGGGTGAAAATGAAATGG & TAACCAAAATGGTTCGTCGG & $241-247$ & 2 & L.hispanicus, L.mutabilis & \\
\hline |112itg42002 & L2 & $(\mathrm{AAC}) 8$ & CTTGCAGGGTCTTCTTACAGC & GGGGTTGTIITTGGTGTCC & $243-246$ & 2 & L.hispanicus & \\
\hline |112itg54849 & L2 & $(A C A) 7$ & TTCTCCAATGATGAAATGCC & TTCACGGCTAAATACCAAGC & 177-183 & 2 & L.hispanicus & Microtubule-associated protein \\
\hline |112itg13638 & L2 & $(\mathrm{TGT}) 9$ & CCATGGTCATCATTAACCCC & CGAGTCGAGTTCGTTTACCC & $188-200$ & 5 & L.hispanicus, L.mutabilis & f-box family protein \\
\hline |112itg26640 & L2 & $(\mathrm{AG}) 7$ & GGTCTGTTGGAGAAGGCTACC & CCACCAATGGGTAGACATACG & 203-209 & 3 & L.hispanicus & Small nuclear ribonucleoprotein \\
\hline |112itg29887 & L2 & $(\mathrm{GCT}) 10$ & CCCATCTGAAAGACTTACGGC & TCCCTTITCATCCAGAGAGG & $243-249$ & 2 & L.hispanicus & Ser/thr-protein kinase AFC2 \\
\hline |112itg50945 & L2 & $(C C A) 6(A C A) 7$ & CCAGAACAAGGAGAAGGTTCC & ТTCTTCTTCCTCGCAGGC & 198-204 & 3 & L.hispanicus & Zinc finger, Transcription factor \\
\hline |112itg44905 & L2 & $(\mathrm{CTT}) 9$ & AAATCACAGAGCCAAGGAGG & TCAGCTTATTTTGTTCCAAGC & $356-362$ & 3 & L.hispanicus, L.mutabilis & Transcription factor \\
\hline |112itg09113 & L2 & (AT)8 & CATGACCCAATCTCAAACCC & GCATCTGGATCTGCTTAATTGG & $341-343$ & 2 & L.hispanicus & \\
\hline |112itg03938 & L2 & (CCGATT)9 & CATGTGGGAAGACCAGAAGC & ACTACGCGCTGCTAATGTCC & $212-290$ & 7 & L.hispanicus, L.mutabilis & Polygalacturonase \\
\hline |112itg32421 & L2 & (AATCGG)8 & AGAGAAGTAGGCATGGTGGC & GATCGGCCTATTCACTCAGC & $221-293$ & 5 & L.hispanicus, L.mutabilis & \\
\hline |112itg29217 & L1, L2 & (AT)7 & ACACTCTCAAGGAAAAGGGC & CCATTTAACCGATAATGCTTGG & $340-344$ & 2 & L.hispanicus & Lactoylglutathione lyase \\
\hline |112itg27515 & L2 & (TTC)17 & CATGCGTCCAATCTATCACC & AGTGGGAAACAAGGAAGTGG & $182-221$ & 8 & L.hispanicus, L.mutabilis & PPR-containing protein \\
\hline |112itg41211 & L2 & $(G A A) 11$ & TCCTCCTGCTTCAGAACG & AAATCCACGTCATCAATCCG & $209-230$ & 6 & L.hispanicus, L.mutabilis & \\
\hline
\end{tabular}


Table 2 cDNA 454 assembly statistics of L1, L2 and L1L2 L. Iuteus libraries

\begin{tabular}{lrrr}
\hline Library statistics & \multicolumn{3}{c}{ L.luteus EST-library } \\
\cline { 2 - 4 } & \multicolumn{1}{c}{ L1 } & \multicolumn{1}{c}{ L2 } & \multicolumn{1}{c}{ L1L2 } \\
\hline Number of sequenced bases & $205,618,165$ & $530,678,975$ & $736,297,140$ \\
Number of reads & 755,206 & $1,468,202$ & $2,213,408$ \\
Number of reads assembled & 604,869 & $1,345,892$ & $1,964,517$ \\
Read average length & 276 & 361 & 332 \\
Number of contigs & 26,975 & 43,674 & 71,655 \\
Contig average size & 589 & 986 & 901 \\
Number of isotigs & 21,235 & 35,191 & 55,309 \\
Isotig average size & 589 & 986 & 901 \\
Number of isogroups & 15,295 & 24,653 & 36,886 \\
Isogroup average size & 589 & 989 & 905 \\
Average number of & 22.4 & 30.8 & 27.4 \\
reads by contig & & & \\
\%GC & 30.7 & 39.9 & 37.5 \\
Annotated sequences & & & 32,862 \\
Gbrowse mapped sequences & & & 25,400 \\
\hline
\end{tabular}

between yellow lupin and Medicago. Thirty-three out of 79 (42\%) primer pairs amplified clear PCR products. 16 pairs showed expected sizes based on Medicago genomic regions. The remainder primer pairs amplified shorter or longer lupin fragments than the fragments amplified in $M$. truncatula. Amplicon sequence data for L. luteus containing intergenic DNA sequence were mapped onto the Medicago genome using blast (Figure 3). The alignments between L. luteus and Medicago showed high levels of conservation in the coding regions, but little sequence similarity in the intergenic regions. When $L$. hispanicus DNA was included as PCR template, only 23 primer pairs amplified. Variable amplification was likely due to localized sequence polymorphism within the primer binding site (i.e. small indels) and not the lack of microsynteny. This ratio (23/33) is similar to the number of EST-SSRs that were found to amplify fragments in both species. Alignments among L. luteus and L. hispanicus were possible at intergenic regions but sequences were clearly less similar than coding regions.

When these markers were evaluated on the screening panel of diverse germplasm accessions, 10 had length polymorphism for these intergenic regions (Additional file 1). In addition to EST-SSRs, this new Conserved Microsynteny (CMS) marker could be valuable resource for crop improvement with molecular markers.

\section{Identification of EST-SSRs}

A total of 2,572 isotig sequences contained at least one EST-SSR, with a frequency of one SSR per 17.75 kilobases (Table 3). The observed frequencies for di-, tri-, tetra-, penta-, and hexa-repeats were $30.4 \%, 52.7 \%, 2.4 \%$, $7.5 \%$ and $6.2 \%$, respectively (Table 4 ). Among the dinucleotide repeats, the AT/TA motif was the most frequently observed (49\%) followed by GA/CT (45\%). The $\mathrm{AC} / \mathrm{GT}$ motif was found in low frequency $(6 \%)$ and there were no CG/GC motifs in the Lupinus sequences. Tri-nucleotide repeats, predominantly A/T-rich motifs (74.5\%), were the most frequent tri-nucleotide repeat found in the Lupinus transcriptome. These trinucleotide repeats were often found within the coding sequence of putative genes (77.2\%). GAA/CTT motif was the most frequent tri-nucleotide repeat (31\%).

\section{Evaluation of EST-SSRs within yellow lupin and other lupin species}

Studies involving repeat sizes and level of polymorphism have suggested a positive correlation between repeat number and rates of polymorphisms, especially in dimeric microsatellites [28,42]. Thus, only EST-SSRs containing at least 7 repeat units were selected for validation to increase the likelihood of finding markers polymorphic between lupin accessions. A total of 783 EST-SSR candidate loci had sufficient repeat units, but only 375 had enough repeat flanking sequence to be suitable for primer design. PCR amplification of these markers resulted in 222 EST-SSRs (59\%) that were polymorphic among the six diverse L. luteus included in screening panel. 130 EST-SSRs were monomorphic and 23 primer-pairs failed to amplify. A small number (6) of EST-SSRs were validated by Sanger sequencing. The amplicon sequences from four different $L$. luteus genotypes and from L. hispanicus and L. mutabilis confirmed the existence of SSR motifs and their length variability between lupin accessions (Figure 4). EST-SSR amplicons showed high conservation at the flanking SSR regions of both Lupinus species when compared with $L$. luteus. However, several indels were observed in adjacent regions and within the SSR motif, especially in $L$. mutabilis.

Fifty polymorphic EST-SSRs were used to genotype a sample of $64 \mathrm{~L}$. luteus accessions (Table 1 and Additional file 2). Twenty-four of these selected markers were specific to L1 (leaf-flower EST library), 20 EST-SSRs were specific to L2 (seed EST library), and 6 were present in both libraries. Neighbor-joining distance analysis detected several clusters among L. luteus accessions, strongly suggesting the existence of population subdivisions (Figure 5). However, no clear geographical patterns (country of origin) were observed among lupin accessions. Interestingly, Chilean accessions were distributed in most clusters, probably reflecting the breeding history of these genotypes. Two hundred and fifty four (65.7\%) and $113(30 \%)$ SSR primer pairs were able to amplify 


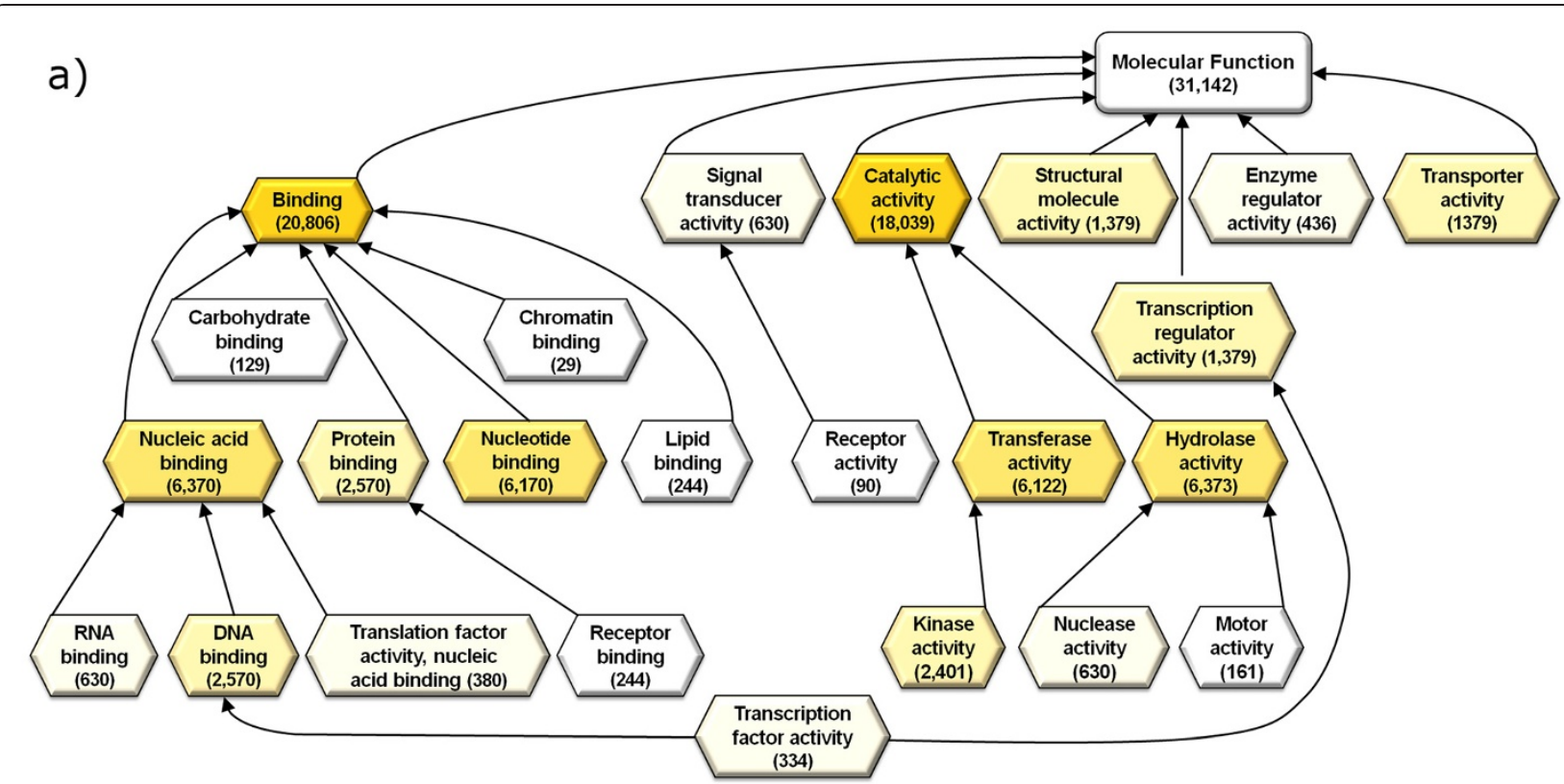

b)

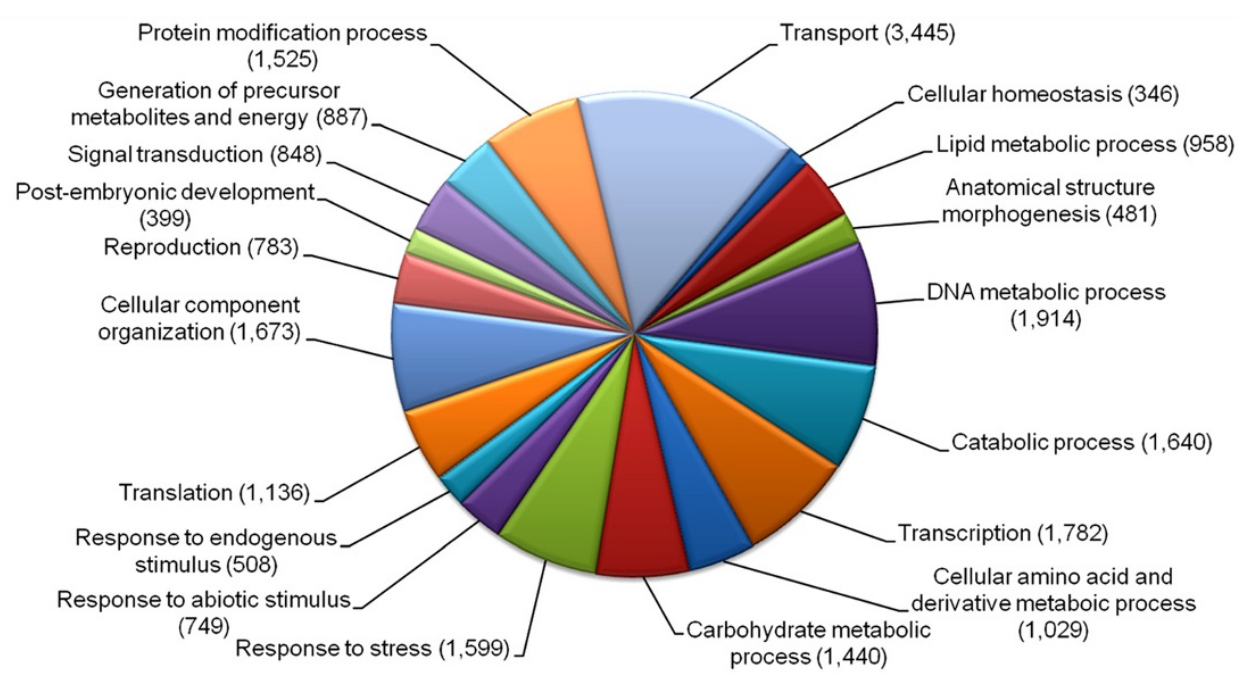

c)

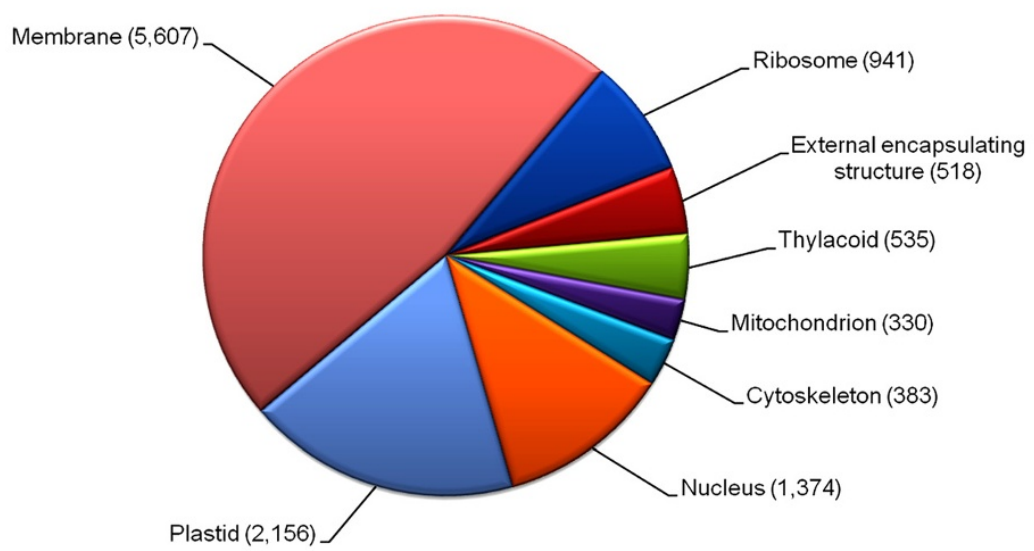

Figure $1 \mathrm{GO}$ term annotations for L1L2. Isotigs were grouped under three categories: (a) molecular function, (b) biological processes, and (c) cellular components. Numbers between parentheses indicate the number of positive matches for each function. 


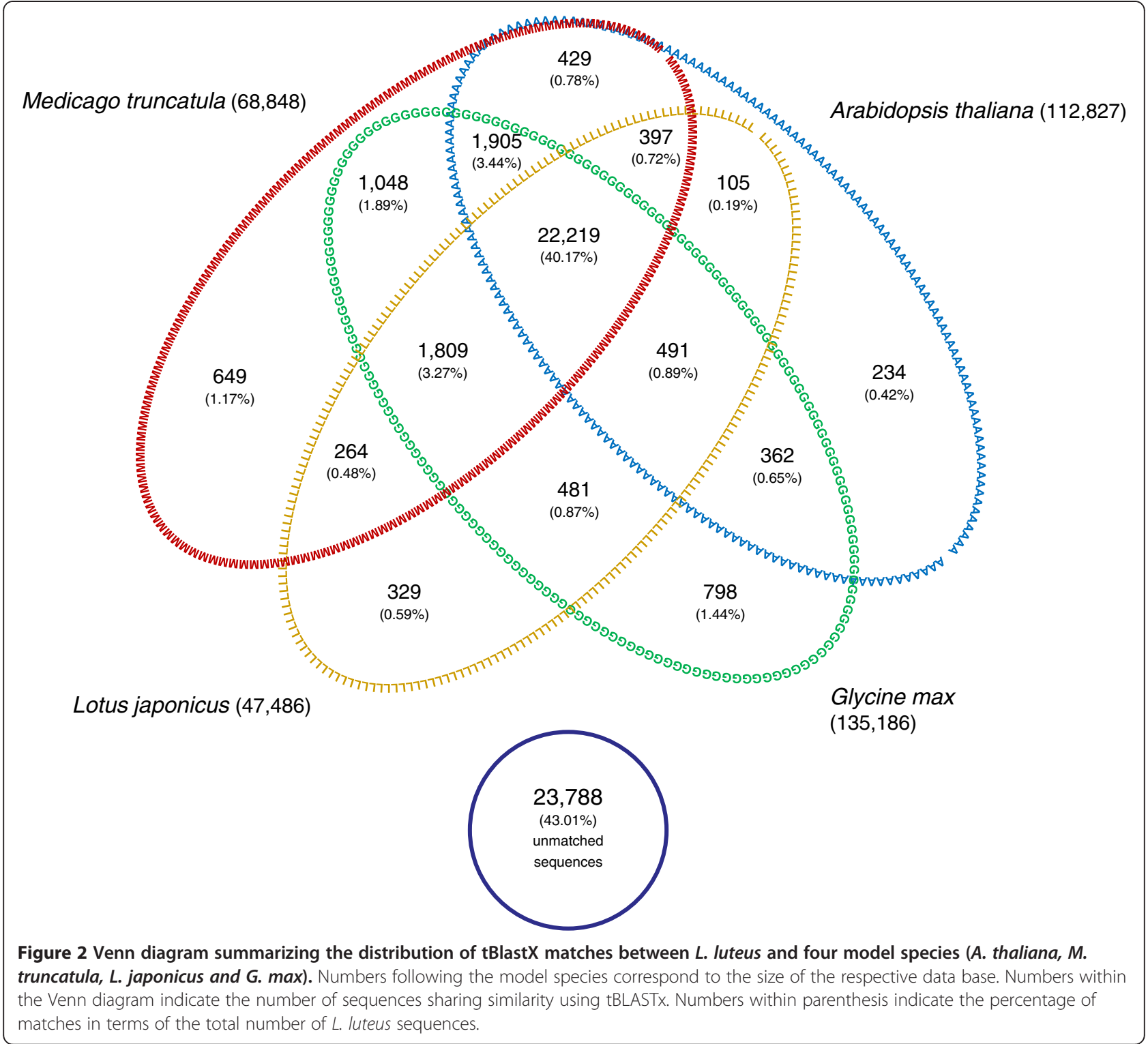

fragments from L. hispanicus and L. mutabilis DNA, respectively.

\section{Discussion}

Next-generation sequencing has reduced the existing gap between major crop genomic platforms and the limited resources that are currently available for orphan crops [10]. Complete transcriptome sequencing has generated species specific molecular markers, in silico expression analyses, gene discovery, and phylogenetic relationships $[43,44]$.

In this research, we used $454 \mathrm{cDNA}$ sequences to assemble transcriptomes of two tissues (L1 and L2) of yellow lupin. We recovered a large number of previously unknown and uncharacterized yellow lupin gene sequences (Table 2). The total number of sequences for the combined library was mostly additive from L1 and L2. The L1 library favored the inclusion of longer 3'UTR regions, and thus, reducing the amount of coding sequences needed to assemble longer combined contigs (L1L2). As a consequence, two or more sequences belonging to the same transcript may not be assembled together, causing an overestimation of expressed sequences. The larger amount of 3'UTR regions for L1 is also in agreement with the lower GC content, condition typically associated with untranslated regions [45,46]. Undoubtedly, a number of expressed sequences are tissue specific and will not assemble into combined contigs. For instance, several genes related to seed dormancy and germination are not expressed in vegetative and floral tissues $[47,48]$. The same specificity was observed in a number of tissues and plant species [49-51]. The 


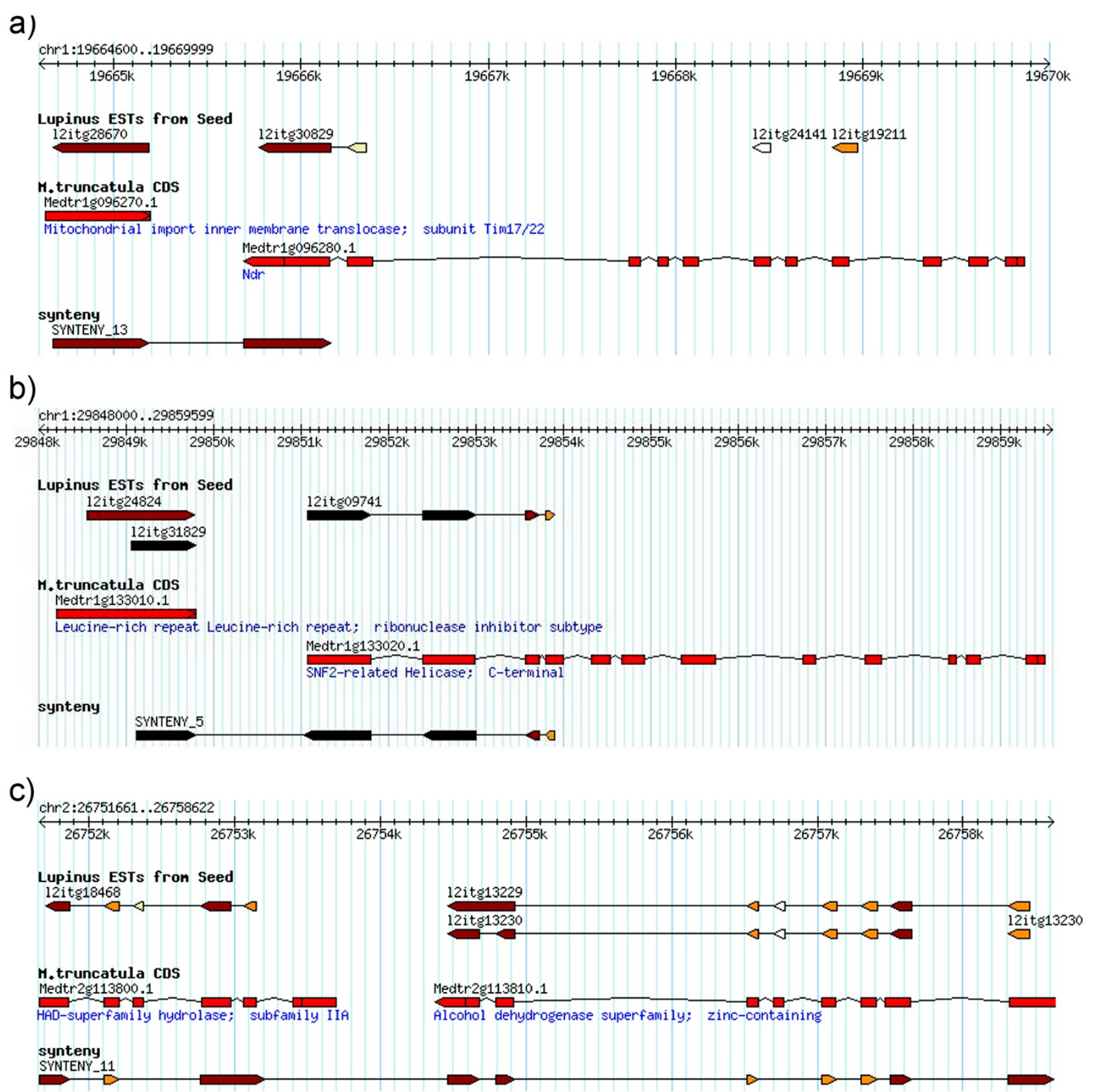

Figure 3 Microsyntenic $L$. luteus DNA fragments mapped on the Medicago genome using a GBrowse platform. (a) L. luteus microsyntenic region 13 on M. truncatula chromosome 1; (b) L. luteus microsyntenic region 5 on M. truncatula chromosome 1; (c) L. luteus microsyntenic region 11 on M. truncatula chromosome 2 .

assembly of L1L2 generated 55,309 isotigs of which 30,811 had similarity to putative proteins found in other plant species. Comparative studies carried out against L. japonicus, M. truncatula and G. max showed a total of 31,520 lupin sequences similar to at least one of the model legume databases and 22,219 were similar to all of them. Lotus and Medicago belong to the Galegoid subclade, which includes mostly temperate legume species [52]. Glycine is a member of the Phaseoloid subclade which comprises mostly tropical species [52]. Lupins belong to the Genistoid subclade, which is sister (and distant) to most of the described Papilionoid subclades; especially those containing most domesticated species [53].

Although micro-repeat motifs are frequent in plant genomes and their respective transcriptomes, the frequency of SSR discovery depends on the search criteria [42,54-56]. We analyzed 55,309 lupin isotig sequences using MISA and identified 2,796 SSR motifs with an average frequency of one SSR per $17.75 \mathrm{kbp}$. Tri-nucleotide 
Table 3 Features of EST-SSRs identified in assembled L1L2 L. luteus library

\begin{tabular}{lr}
\hline Total number of examined sequences & 55,309 \\
\hline Estimated transcriptome screened (kbp) & 49,841 \\
\hline Number of sequences containing SSRs & 2,572 \\
\hline Number of identified SSR & 2,774 \\
\hline Number of EST-SSRs in coding regions & 1,435 \\
\hline Number of sequences containing more than 1 SSRs & 147 \\
\hline Number of SSRs present in compound formation & 195 \\
\hline Frequency of SSR in transcriptome & $1 / 18 \mathrm{Kbp}$ \\
\hline
\end{tabular}

Table 4 Distribution of repeat types and number of repeats within the L1L2 L. Iuteus library

\begin{tabular}{|c|c|c|c|c|c|c|c|c|}
\hline \multirow[t]{2}{*}{ Repeat type } & \multicolumn{7}{|c|}{ Number of repeat units } & \multirow[t]{2}{*}{ Total (\%) } \\
\hline & 4 & 5 & 6 & 7 & 8 & 9 & $>10$ & \\
\hline Di-nucleotide & & & 363 & 204 & 120 & 72 & 91 & $851(30.7)$ \\
\hline Tri-nucleotide & & 826 & 369 & 131 & 69 & 25 & 57 & $1477(53.2)$ \\
\hline Tetra-nucleotide & & 43 & 9 & 3 & 1 & 2 & 8 & $66(2.4)$ \\
\hline Penta-nucleotide & 129 & 46 & 6 & 3 & 9 & 6 & 12 & $209(7.5)$ \\
\hline Hexa-nucleotide & 105 & 26 & 11 & 3 & 9 & 5 & 13 & $171(6.2)$ \\
\hline
\end{tabular}

repeats were the motifs most frequently found in L. luteus expressed sequences. Similar results have been reported in numerous plant species $[26,28,54,55,57]$. The abundance of trimeric EST-SSRs has been attributed to the absence of frameshift mutations when there is length variation in these SSRs [58]. Indeed, 1,435 EST-SSRs were discovered within coding regions of the gene. Among tri-nucleotide repeats, AT-rich motifs were the most predominant ones (74.5\%), which have also been observed in soybean, Citrus and Arabidopsis [54,57]. For di-nucleotide repeats, AT was the most frequently observed motif, contrasting with results from Arabidopsis, soybean, maize, rice, wheat and barley where AC/GT were the most frequent repeats $[26,28,54,55,57]$. The high proportion of untranslated sequences (specifically
3'UTR), mainly contributed from the L1, could explain the bias toward A/T-rich repeat sequences observed in yellow lupin. There were no CG repeats in the lupin sequences, similar to results obtained in barrel medic [24], rice, corn, soybean [57], wheat [27], Sorghum [25], Arabidopsis, apricot and peach [59].

We used GBrowse to visualize lupin ESTs aligned to the M. truncatula chromosomes (Figure 3). This approach potentially identifies paralogs sequences and allows color-coded alignment by BLAST significance [60]. A total of $25,400 \mathrm{~L}$. luteus contigs were localized and found to be distributed across the entire Medicago genome with chromosomes Mt1 and Mt3 having the highest number of gene matches. Each yellow lupin sequence was mapped to an average of 3.7 locations, which may correspond in part to rounds of genome duplications previously described for the Medicago genome [61]. Understanding syntenic relationships among species is essential to exploit the available tools developed for comparative genomic analysis. Using this approach, we created a new method of developing molecular markers, markers that are based on conserved microsynteny (CMS) between orphan and model species. Genome comparisons among M. truncatula, G. max and L. japonicus have shown that, in general, most genes in Papilionoid legume species are likely to be found within a relatively long syntenic region of any other Papilioniod species [62]. Positive amplification and sequencing of L. luteus intergenic regions, based on PCR primers located on $M$. truncatula adjacent genes, suggested the existence of microscale synteny between these legume species. Roughly $40 \%$ of the targeted intergenic L. luteus regions amplified, points out the usefulness of conserved legume chromosome blocks for genomic studies of orphan crops. Although some primer pairs failed to amplify, poor amplification could be a consequence of non-synteny, but also other technical limitations could also explain negative PCR results. For instance it is known that non-coding DNA regions are highly variable among species $[63,64]$, and negative PCR

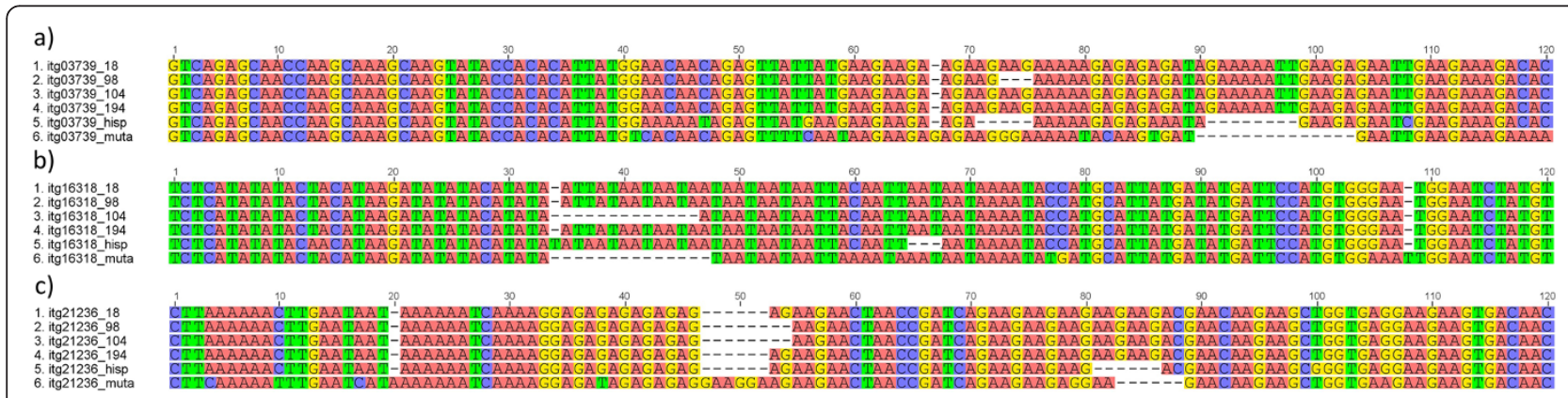

Figure 4 Alignment of L. luteus, L. hispanicus and L. mutabilis containing several repeat motifs. (a) isotig03739 with GA and AGA motifs; (b) isotig 16318 with a TAA motif; and (c) isotig21236 with a GAA motif. 


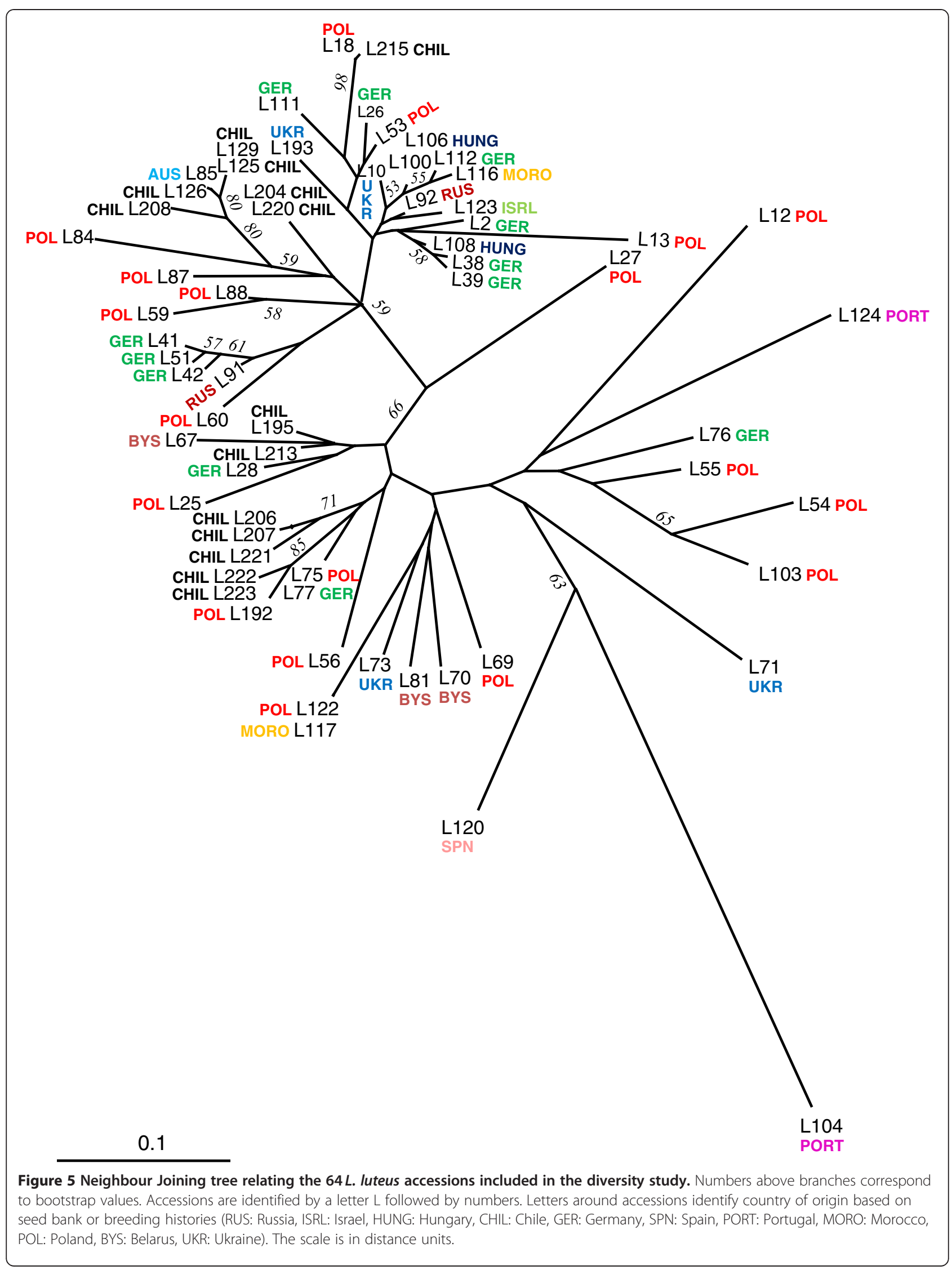


amplifications could easily due to excessively long L. luteus intergenic regions.

Few studies have reported the use of EST-SSRs in Lupinus species $[19,21,22]$. Most efforts have focused on genetic linkage mapping and in diversity studies in L. angustifolius [20], L. albus [21] and L. luteus [22]. To validate our $L$. luteus polymorphic markers we tested 50 EST-SSRs on a population of 64 genotypes of L. luteus. An analysis of genotypic diversity illustrated the existence of several clusters within L. luteus germplasm. The lack of a clear pattern following the geographical accession origin (country) could be explained by three reasons. 1) The number of accessions may not have been large enough to allow a clear pattern to emerge. 2) L. luteus is widely distributed across the Mediterranean region, mainly due to human introductions [6]. This situation could have homogenized natural genetic distinctiveness, leaving mostly population subdivisions based on breeding histories. 3) Finally, it is possible some accessions could have been misclassified; and thus, obscuring an existing geographical clustering pattern.

We observed that a number of high yellow lupin ESTSSR amplified fragments in two other lupin species, L. hispanicus and L. mutabilis (Table 1). The high number of transferable markers between $L$. luteus and L. hispanicus confirmed their closer genetic relationship $[5,65]$ than L. luteus and L. mutabilis. The two closely related species have the same chromosome number $(2 n=52)$ and are still interfertile, generating a natural hybrid called hispanicoluteus [66]. Phylogenetic studies have placed new and old world lupins into two different clades [5,65,67]. Thus, most EST-SSRs amplified in L. mutabilis $(2 \mathrm{n}=48)$, the only cultivated new world lupin [65], should have high transferability rates to other lupin species, such as L. albus and L. angustifolius. The understanding of the genetic diversity among other close relative lupin species will facilitate the transfer of favorable variation into cultivated species. For instance, $L$. hispanicus has been suggested as a reservoir of favorable variation for a number of biotic and abiotic stresses currently affecting $L$. luteus $[68,69]$.

\section{Conclusion}

L. luteus deep transcriptome sequencing will facilitate the further development of genomic tools and lupin germplasm. Massive sequencing of cDNA libraries will continue to produce raw materials for gene discoveries, identification of polymorphisms (SNPs, EST-SSRs, INDELs, etc.) for marker development, anchoring sequences for genome comparison studies and putative gene candidates for QTL detection. We are also exploiting the microsyntenic regions observed among L. luteus and legume model species to saturate yellow lupin linkage maps by amplifying conserved regions across legume species. The utilization of these tools will allow transforming $L$. luteus into a valid temperate legume crop alternative.

\section{Additional files}

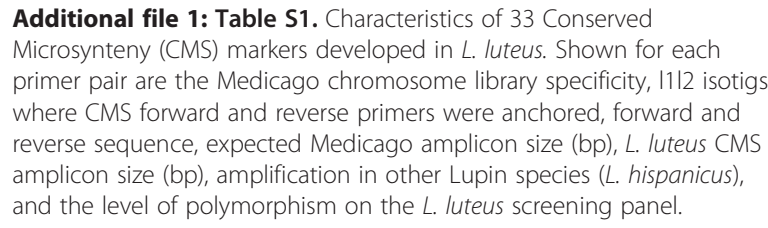

Additional file 2: Table S2. Lupinus luteus, L. hispanicus and

L. mutabilis accessions included in the study.

\section{Competing interests}

The authors declare that they have no competing interests.

\section{Authors' contributions}

LBP collected the tissues and extracted the RNAs. JU, LBP and JM constructed the EST libraries. $J U$ and JM supervised the 454 sequencing of the libraries. LBP and JU conducted the SSR search and primer design. LBP conducted the SSR polymorphism tests and transferability studies. LMP sequenced the amplicons of SSR and intergenic blocks. GAA grew the plants for the diversity study, extracted the DNAs, PCR amplified and conducted the genotyping of the population. IMB drafted the experimental design of all the studies carried out in this work and conducted the genetic analysis for the diversity study. CSN conducted annotations and in silico mapping of the sequences. LBP conducted the microscale synteny studies. HS and IMB conceived the study. LBP drafted the manuscript with the support of IMB. All the authors read and approved the final manuscript.

\section{Acknowledgments}

This research was funded by the National Commission for Scientific \& Technological Research (FONDECYT Project No.1090759) and CONICYT Regional/GORE Araucanía/CGNA/R10C1001, Chile. We thank Héctor Urbina for his assistance on L. luteus sequence assemblies.

\section{Author details}

'Agriaquaculture Nutritional Genomic Center, CGNA, Genomics and Bioinformatics Unit, Km 10 Camino Cajón-Vilcún, INIA, Temuco, Chile. ${ }^{2}$ Plant and Wildlife Science Department, Brigham Young University, 150 E 1230 North, Provo, UT 84602, USA. ${ }^{3}$ Institute of Agricultural Research (INIA), P.O. Box 58-D, Temuco, Chile.

Received: 9 May 2012 Accepted: 13 August 2012 Published: 24 August 2012

\section{References}

1. Mace ES, Varshney RK, Mahalakshmi V, Seetha K, Gafoor A, Leeladevi Y, Crouch JH: In silico development of simple sequence repeat markers within the aeschynomenoid/dalbergoid and genistoid clades of the Leguminosae family and their transferability to Arachis hypogaea, groundnut. Plant Sci 2008, 174:51-60.

2. Gladstones JS: Distribution, origin, taxonomy, history and importance. In Lupins as crop plants: biology, production and utilization. Edited by Gladstones JS, Atkins CA, Hamblin J, Gladstones JS, Atkins CA, Hamblin J. Cambridge, United Kingdom: CAB International; 1998:1-37.

3. Múzquiz M, Burbano C, Gorospe MJ, Ródenas I: A chemical study of Lupinus hispanicus seed-toxic and antinutritional components. J Scie Food Agr 1989, 47:205-214.

4. Wolko B, Weeden NF: Estimation of Lupinus genome polyploidy on the basis of isozymic loci number. Genet Pol 1989, 30:165-170.

5. Naganowska B, Wolko B, Sliwinska E, Kaczmarek Z: Nuclear DNA content variation and species relationships in the genus Lupinus (Fabaceae). Ann Bot 2003, 92:349-355. 
6. Petterson DS: Composition and food uses of lupin. In Lupins as a crop plants: biology, production and utilization. Edited by Gladstones JS, Atkins CA, Hamblin J. Wallingford, UK: CAB International; 1998:353-384.

7. Gladstones JS: Lupins of the Mediterranean Region and Africa. Technical Bulletin No. 26. Western Australia: Western Australian Department of Agriculture; 1974:43-48.

8. Glencross BD, Carter CG, Duijster N, Evans DR, Dods K, McCafferty P, Hawkins WE, Maas R, Sipsas S: A comparison of the digestibility of a range of lupin and soybean protein products when fed to either Atlantic salmon (Salmo salar) or rainbow trout (Oncorhynchus mykiss). Aquaculture 2004, 237:333-346.

9. Berville ABS, Heinanen J, Kartuzova LT, Bernatskaya ML, Chmeleva ZV: Diversity of lupin (Lupinus L.) based on biochemical composition. Plant Genet Res Newsletter 2003, 134:42-57.

10. Varshney RK, Close TJ, Singh NK, Hoisington DA, Cook DR: Orphan legume crops enter the genomics era! Curr Opin Plant Biol 2009, 12:202-210.

11. Kaur S, Cogan N, Pembleton LW, Shinozuka M, Savin KW, Materne M, Forster $J W$ : Transcriptome sequencing of lentil based on second-generation technology permits large-scale unigene assembly and SSR marker discovery. BMC Genomics 2011, 12:265.

12. Hiremath PJ, Farmer A, Cannon SB, Woodward J, Kudapa H, Tuteja R, Kumar A, Bhanuprakash A, Mulaosmanovic B, Gujaria N, Krishnamurthy L, Gaur PM, Kavikishor PB, Shah T, Srinivasan R, Lohse M, Xiao Y, Town CD, Cook DR, May GD, Varshney RK: Large-scale transcriptome analysis in chickpea (Cicer arietinum L.), an orphan legume crop of the semi-arid tropics of Asia and Africa. Plant Biotechnol J 2011, 9:922-931.

13. Cheung F, Haas BJ, Goldberg SMD, May GD, Xiao Y, Town CD: Sequencing Medicago truncatula expressed tags using 454 Life Science technology. BMC Genomics 2006, 7:272.

14. Weber APM, Weber KL, Carr K, Wilkerson C, Ohlrogge JB: Sampling the Arabidopsis transcriptome with massively parallel pyrosequencing. Plant Physiol 2007, 144:32-42.

15. Yu JK, La Rota M, Kantety RV, Sorrells ME: EST derived SSR markers for comparative mapping in wheat and rice. Mol Genet Genomics 2004, 271:742-751.

16. Rexroad CE III, Rodriguez MF, Coulibaly I, Gharbi K, Danzmann RG, DeKoning J, Phillips R, Palti Y: Comparative mapping of expressed sequence tags containing microsatellites in rainbow trout (Oncorhynchus mykiss). BMC Genomics 2005, 6:54.

17. Young ND, Udvardi M: Translating Medicago truncatula genomics to crop legumes. Curr Opin Plant Biol 2009, 12:193-201.

18. Aubert G, Morin J, Jacquin F, Loridon K, Quillet MC, Petit A, Rameau C, Lejeune-Henaut I, Huguet T, Bursting J: Functional mapping in pea, as an aid to the candidate gene selection and for investigating synteny with the model legume Medicago truncatula. Theor Appl Genet 2006, 112:1024-1041.

19. Phan HT, Ellwood SR, Adhikari K, Nelson MN, Oliver RP, Phan HT, Ellwood SR, Adhikari K, Nelson MN, Oliver RP: The first genetic and comparative map of white lupin (Lupinus albus L.): Identification of QTLs for anthracnose resistance and flowering time, and a locus for alkaloid content. DNA Res 2007, 14:59-70.

20. Nelson MN, Moolhuijzen PM, Boersma JG, Chudy M, Lesniewska K, Bellgard M, Oliver RP, Swiecicki W, Wolko B, Cowling WA, Ellwood SR: Aligning a New Reference Genetic Map of Lupinus angustifolius with the Genome Sequence of the Model Legume, Lotus japonicus. DNA Res 2010, 17:73-83.

21. Nelson M, Huyen P, Ellwood S, Moolhuijzen P, Hane J, Williams A, O'Lone C, Fosu-Nyarko J, Scobie M, Cakir M, Jones M, Bellgard M, Ksiazkiewicz M, Wolko B, Barker S, Oliver R, Cowling W: The first gene-based map of Lupinus angustifolius L.-location of domestication genes and conserved synteny with Medicago truncatula. Theor Appl Genet 2006, 113:225-238.

22. Parra Gonzalez L, Straub S, Doyle J, Mora Ortega P, Salvo Garrido H, Maureira Butler I: Development of microsatellites in Lupinus luteus (Fabaceae) and cross-species amplification in other lupine species. Am J Bot 2010, 97:e72-e74.

23. Gao LL, Hane JK, Kamphuis LG, Foley R, Shi BJ, Atkins CA, Singh KB: Development of genomic resources for the narrow-leafed lupin (Lupinus angustifolius): construction of a bacterial artificial chromosome (BAC) library and BAC-end sequencing. BMC Genomics 2011, 12:521.

24. Gupta S, Prasad M: Development and characterization of genic SSR markers in Medicago truncatula and their transferability in leguminous and non-leguminous species. Genome 2009, 52:761-771.
25. Kantety RM, Mathews DE, Sorrels ME: Data mining for simple sequence repeats in expressed sequence tags from barley, maize, rice, sorghum and wheat. Plant Mol Biol 2002, 148:501-510.

26. La Rota RM, Kantety RV, Yu JK, Sorrells ME: Nonrandom distribution and frequencies of genomic and EST-derived microsatellite markers in rice, wheat, and barley. BMC Genomics 2005, 6:23-35.

27. Nicot $N$, Chiquet VB, Amilhat L, Legeai F, Leroy P, Bernard M, Sourdille P: Study of simple sequence repeat (SSR) markers from wheat expressed sequence tags (ESTs). Theor Appl Genet 2004, 109:800-805.

28. Thiel T, Michalek W, Varshney RK, Graner A: Exploiting EST databases for the development and characterization of gene-derived SSR-markers in barley (Hordeum vulgare L.). Theor App/ Genet 2003, 106:411-422.

29. Domon E, Fuijita M, Ishikawa N: The insertion/deletion polymorphisms in the waxy gene of barley genetic resources from East Asia. Theor Appl Genet 2002, 104:132-138.

30. Blair M, McCouch SR: Microsatellite and sequence-tagged site markers diagnostic for the rice bacterial leaf blight resistance gene xa-5. Theor Appl Genet 1997, 95:174-184.

31. Ayres NM, McClung AM, Larkin PD, Bligh HFJ, Jones CA, Park WD: Microsatellites and a single nucleotide polymorphism differenciate apparent amylase classes in an extended pedigree of US rice germplasm. Theor App/ Genet 1997, 94:773-781.

32. Prathepha P: Characterization of Waxy microsatellite classes that are closely linked to the rice Waxy gene and amylose content in Thai rice germplasm Songklanakarin. J Sci Technol 2003, 25:1-8.

33. Selvaraj I, Nagarajan P, Thiyagarajan K, Bharathi M, Rabindran R: Identification of Microsatellite (SSR) and RAPD Markers Linked to Rice Blast Disease Resistance gene in Rice (Oryza sativa L.). African J Biotechnol 2011, 10:3301-3321.

34. Zhou WC, Kolb FL, Bai GH, Domier LL, Boze LK, Smith NJ: Validation of a major QTL for scab resistance with SSR markers and use of markerassisted selection in wheat. Plant Breeding 2003, 122:40-46.

35. Abdurakhmonov IY, Abdullaev AA, Saha S, Buriev ZT, Arslanov D, Kuryazov Z, Mavlonov GT, Rizaeva SM, Reddy UK, Jenkins JN, Abdullaev A, Abdukarimov A: Simple Sequence Repeat Marker Associated with a Natural Leaf Defoliation Trait in Tetraploid Cotton. J Hered 2005, 96:644-653.

36. Zeng L, Meredith WR Jr, Gutiérrez OA, Boykin DL: Identification of associations between SSR markers and fiber traits in an exotic germplasm derived from multiple crosses among Gossypium tetraploid species. Theor Appl Genet 2009, 119:93-103.

37. Li X, Yang H, Buirchell B, Yan G: Development of a DNA marker tightly linked to low-alkaloid gene iucundus in narrow-leafed lupin (Lupinus angustifolius L.) for marker-assisted selection. Crop and Pasture Sci 2011, 62:218-224.

38. Logeman J, Schell J, Willmitzer L: Improved method for the isolation of RNA from plant tissues. Anal Biochem 1987, 163:16-20.

39. Meyer E, Aglyamova GV, Wang S, Buchanan-Carter J, Abrego D, Colbourne $\mathrm{JK}$, Willis BL, Matz MV: Sequencing and de novo analysis of a coral larval transcriptome using 454 GSFIx. BMC Genomics 2009, 10:219.

40. Podicheti R, Gollapudi R, Dong Q: WebGBrowse: a web server for GBrowse. Bioinformatics 2009, 25:1550-1551.

41. Doyle JJ, Doyle JL: A rapid DNA isolation procedure for small quantities of fresh leaf tissue. Phytochem Bull 1978, 19:11-15.

42. Temnykh S, DeClerck G, Lukashova A, Lipovich L, Cartinhour S, McCouch S: Computational and experimental analysis of microsatellites in rice (Oryza sativaL.): Frequency, length variation, transposon associations, and genetic marker potential. Genome Res 2001, 11:1441-1452.

43. Edwards D, Batley J: Plant genome sequencing: applications for crop improvement. Plant Biotech J 2010, 8:2-9.

44. Lister R, Gregory BD, Ecker JR: Next is now: new technologies for sequencing of genomes, transcriptomes, and beyond. Curr Opin Plant Biol 2009, 12:107-118.

45. Zhang L, Kasif S, Cantor CR, Broude NE: GC_AT-content spikes as genomic punctuation marks. Proc Natl Acad Sci 2004, 101:16855-16860.

46. Pesole G, Liuni S, Grillo G, Licciulli F, Mignone F, Gissi C, Saccone C: UTRdb and UTRsite: specialized database of sequences and functional elements of $5^{\prime}$ and $3^{\prime}$ unstranslated regions of eukaryotic mRNAs. Update 2002. Nucleic Acids Res 2002, 30:335-340.

47. Diaz I, Vicente-Carbajosa J, Abraham Z, Martinez M, Isabel-La Moneda I, Carbonero P: The GAMYB protein from barley interacts with the DOF transcription factor BPBF and activates endosperm-specific genes during seed development. Plant J 2002, 29:453-464. 
48. Koornneff M, Bentsink L, Hilhorst $H$ : Seed dormancy and germination. Curr Opin Plant Biol 2002, 5:33-36.

49. Tillett RL, Ergül A, Albion RL, Schlauch KA, Cramer GR, Cushman JC: Identification of tissue-specific, abiotic stress responsive gene expression patterns in wine grape (Vitis vinifera L.) based on curation and mining of large-scale EST data sets. BMC Plant Biology 2011, 11:86.

50. Covitz PA, Smith LS, Long SR: Expressed Sequence Tags from a RootHair-Enriched Medicago truncatula cDNA Library. Plant Physiol 1998, 117:1325-1332.

51. Yamada S, Katsuhara M, Kelly WB, Michalowski CB, Bohnert HJ: A family of transcripts encoding water channel proteins: Tissue-specific expression in the common ice plant. Plant Cell 1995, 7:1129-1142.

52. Bertioli DJ, Moretzsohn MC, Madsen LH, Sandal N, Leal-Bertioli S, Guimarães PM, Hougaard BK, Fredslund J, Schauser L, Nielsen AM, Sato S, Tabata S, Cannon SB, Stougaard J: An analysis of synteny of Arachis with Lotus and Medicago sheds new light on the structure, stability and evolution of legume genomes. BMC Genomics 2009, 10:45.

53. Wojciechowski MF, Lavin M, Sanderson MJ: A phylogeny of legumes (leguminosae) based on analysis of the plastid MATK gene resolves many well-supported subclades within the family. Am J Bot 2004, 91:1846-1862.

54. Cardle I, Ramsay L, Milbourne D, Macaulay M, Marshall D, Waugh R: Computational and experimental characterization of physically clustered simple sequence repeats in plants. Genetics 2000, 156:847-854.

55. Varshney RK, Thiel T, Stein N, Langridge P, Graner A: In silico analysis on frequency and distribution of microsatellites in ESTs of some cereals species. Cell Mol Biol Lett 2002, 7:537-546.

56. Varshney RK, Graner A, Sorrels ME: Genic microsatellite markers in plants: features an applications. Trends Biotechnol 2005, 23:48-55.

57. Gao L, Tang J, Li H, Jia J: Analysis of microsatellites in major crops assessed by computational and experimental approaches. Mol Breeding 2003, 12:245-261.

58. Metzgar D, Bytof J, Wills C: Selection against frameshift mutations limits expansion in coding DNA. Genome Res 2000, 10:72-80.

59. Jung S, Abbott A, Jesudurai C, Tomkins J, Main D: Frequency, type, distribution and annotation of simple sequence repeats in Rosaceae ESTs. Funct Integr Genomics 2005, 5:136-143.

60. Beckett P, Bancroft I, Trick M: Computational tools for Brassica-Arabidopsis comparative genomics. Comp Funct Genom 2005, 6:147-152.

61. Shoemaker RC, Schlueter J, Doyle JJ: Paleopolyploidy and gene duplication in soybean and other legumes. Curr Opin Plant Biol 2006 9:104-109.

62. Mudge J, Cannon SB, Kalo P, Oldroyd GED, Roe BA, Town CD, Young ND: Highly syntenic regions in the genomes of soybean, Medicago truncatula, and Arabidopsis thaliana. BMC Plant Biology 2005, 5:15.

63. Grover CE, Wendel JF: Recent insights into mechanisms of genome size change in plants. J Botany 2010 2010, Article ID 382732:1-8.

64. Bruggmann R, Bharti AK, Gundlach H, Lai J, Young S, Pontaroli AC, Wei $F$ Haberer G, Fuks G, Du C, Raymond C, Estep MC, Liu R, Bennetzen JL, Chan AP, Rabinowicz PD, Quackenbush J, Barbazuk WB, Wing RA, Birren B, Nusbaum C, Rounsley S, Mayer FX, Messing J: Uneven chromosome contraction and expansion in the maize genome. Genome Res 2006, 16:1241-1251.

65. Ainouche AK, Bayer R: Phylogenetic relationships in Lupinus (Fabaceae: Papilionoideae) based on internal transcribed spacer sequences (ITS) of nuclear ribosomal DNA. Am J Bot 1999, 86:590-607.

66. Swiecicki W, Swiecicki WK, Nijaki T: Lupinus $\mathrm{x}$ hispanicoluteus - An interspecific hybrid of Old world lupins. Acta Soc Bot Pol 1999, 68:217-220.

67. Drummond CS: Diversification of Lupinus (Leguminosae) in the western New World: Derived evolution of perennial life history and colonization of montane habitats. Mol Phylogenet Evol 2008, 48:408-421.

68. Callow JA, Ford-Lloyd BV, Newbury HJ: Biotechnology and plant genetic resources: conservation and use. Wallingford, UK: CAB International; 1997:49-76.

69. Swanson T: Global values of Biological diversity: the public interest in the conservation of plant genetic resources for agriculture. Plant Genet Res Newsletter 1996, 105:1-3.

doi:10.1186/1471-2164-13-425

Cite this article as: Parra-González et al.: Yellow lupin (Lupinus luteus L.) transcriptome sequencing: molecular marker development and comparative studies. BMC Genomics 2012 13:425.

\section{Submit your next manuscript to BioMed Central and take full advantage of:}

- Convenient online submission

- Thorough peer review

- No space constraints or color figure charges

- Immediate publication on acceptance

- Inclusion in PubMed, CAS, Scopus and Google Scholar

- Research which is freely available for redistribution 